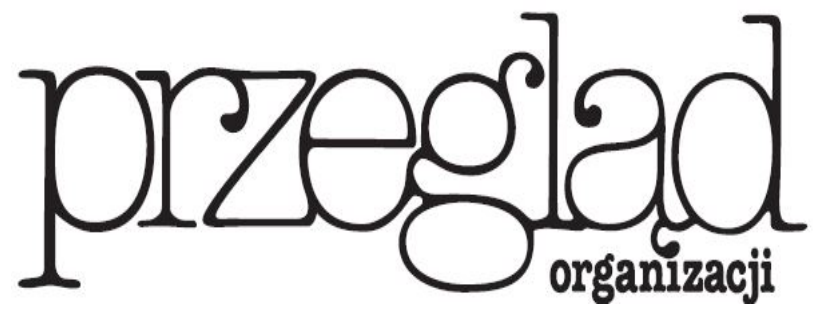

Miesięcznik TNOiK Założył Karol Adamiecki w 1926 r.

\title{
OCENA PROCESU DZIELENIA SIĘ WIEDZA Z PERSPEKTYWY PRAKTYKÓW
}

https://doi.org/10.33141/po.2019.04.07

\section{Sylwia Flaszewska}

\section{Wprowadzenie}

D zielić się wiedzą czy raczej ją chronić? Przed takim dylematem stał chyba każdy z nas. Dla jednych odpowiedź na tak postawione pytanie wydaje się oczywista, dla innych już tak oczywista nie jest. Dotychczasowe doświadczenia przedsiębiorstw potwierdzają, że wprowadzenie praktyki dzielenia się wiedzą stanowi wyzwanie dla firmy, ale jest nieocenione w dłuższej perspektywie. Z kolei zatrzymywanie wiedzy przez pracowników dla siebie hamuje rozwój nie tylko jednostki, ale całej organizacji.

Liczne badania w obszarze dzielenia się wiedzą zawężają tę problematykę do analizy konkretnej branży lub koncentrują się na wybranych jego aspektach, skupiając się np. na skłonności pracowników do dzielenia się wiedzą, wykorzystaniu konkretnych narzędzi czy barierach w tym procesie (Krok, 2011; Ziemba i Eisenbardt, 2016; Carvalho de Almeida i in., 2016; Al Saifi i in., 2016). Uwagę zwraca więc niedostatek opracowań traktujących o kompleksowym podejściu do dzielenia się wiedzą. Całościowe zbadanie procesu dzielenia się wiedzą (jego specyfiki, czynników stymulujących i blokujących, a także korzyści oraz poniesionych nakładów) umożliwi wskazanie działań (wytycznych) pozwalających na poprawę jego efektywności.

Uwzględniając znaczenie procesu dzielenia się wiedzą w rozwoju współczesnych przedsiębiorstw i to, że przyczynia się on nie tylko do sprawniejszego i skuteczniejszego
Przegląd Organizacji, Nr 4 (951), 2019, ss. 45-50 www.przegladorganizacji.pl @Towarzystwo Naukowe Organizacji i Kierownictwa (TNOiK) realizowania zadań, lecz także tworzenia nowej wiedzy stanowiącej często źródło innowacji, jako cel artykułu wyznaczono jego ocenę na podstawie badań przeprowadzonych w 55 przedsiębiorstwach różnej wielkości z województwa łódzkiego.

Artykuł ma charakter teoretyczno-empiryczny. W pierwszej części opracowania wyjaśniono istotę procesu dzielenia się wiedzą z perspektywy teoretycznej. W dalszej kolejności przedstawiono metodykę badań, scharakteryzowano próbę oraz zaprezentowano wybrane $\mathrm{z}$ uzyskanych wyników. $\mathrm{W}$ podsumowaniu zawarto najważniejsze wnioski $\mathrm{z}$ przeprowadzonych rozważań, zwrócono uwagę na ograniczenia badań oraz określono przyszłe wyzwania badawcze.

\section{Dzielenie się wiedzą - perspektywa teoretyczna}

C zęść wspólną wielu teoretycznych rozważań dotyczących dzielenia się wiedzą stanowi słowo proces. Autorzy zgadzają się w kwestii relacji pomiędzy dzieleniem się wiedzą a zarządzaniem nią, stwierdzając, że dzielenie się wiedzą stanowi jeden $\mathrm{z}$ ważniejszych procesów zachodzących w ramach szerszej koncepcji - zarządzania wiedzą (Riege, 2005, s. 18; Flaszewska, Zakrzewska-Bielawska, 2017, s. 344). Podstawowym warunkiem 
pomyślnego zarządzania wiedzą jest bowiem gotowość jednostki do dzielenia się swoją cichą wiedzą z innymi (Hislop, 2013). Niektórzy twierdzą nawet, że w celu osiągnięcia korzyści z zarządzania wiedzą pracownicy muszą być przekonani, że udostępnianie wiedzy leży w ich interesie (Fullwood, Rowley, 2017).

Najogólniej rzecz ujmując, proces dzielenia się wiedzą polega na prezentowaniu, publikowaniu i przekazywaniu wiedzy z wykorzystaniem różnych metod jej rozpowszechniania (Skrzypek, 2018, s. 35). Umożliwia albo tworzenie nowej wiedzy, albo lepsze wykorzystanie tej istniejącej. Odbywa się na poziomach: pojedynczych osób, grupowym, organizacyjnym i międzyorganizacyjnym (Ryszko, 2015, s. 157). Wpływ na jego przebieg ma wiele czynników, które mogą zarówno mu sprzyjać, jak i go utrudniać.

Nie bez znaczenia pozostaje tu kwestia skłonności pracowników do dzielenia się wiedzą, o której poziomie mogą decydować (Krok, 2009, s. 187-192; Krok, 2009a, s. 11-22):

- czynniki zależne od organizacji (integracja idei dzielenia się wiedzą ze strategią biznesową, kultura organizacyjna, poparcie pracy zespołowej, bezpośrednie wsparcie zarządu i „przykład z góry”, zapewnianie czasu i stwarzanie okazji do przekazywania wiedzy, atmosfera, środowisko pracy, brak lęku pracownika o rozwój kariery czy utratę pozycji, docenianie i nagradzanie zachowań związanych z dzieleniem się wiedzą, sprawność systemu komunikacji, dostępność i jakość technologii informacyjnej, wielkość firmy, branża i struktura organizacyjna);

- czynniki interpersonalne (relacje międzyludzkie, odwzajemnianie, zobowiązanie, zaufanie co do właściwego wykorzystania wiedzy, identyfikacja z określonym zachowaniem, unikanie zakłopotania, poczucie przynależności do grupy lub zespołu, dążenie do wspólnoty i współdziałania);

- czynniki indywidualne (chciwość, chęć zysku, strach przed karą, poczucie własnej wartości, cechy osobowości, takie jak między innymi optymizm, pewność siebie, altruizm, otwartość na doświadczenia, koszty i czas przyswojenia wiedzy, wiek, płeć, wykształcenie, stan rodzinny, staż pracy, stanowisko);

- czynniki zależne od wiedzy (typ wiedzy determinujący możliwości i czas jej przekazania).

Z kolei szerokiego przeglądu różnych klasyfikacji barier dzielenia się wiedzą dostarczają m.in.: A. Riege (2005), A. Ujwary-Gil (2012), M. Kukko (2013), E. Skrzypek (2018). Na potrzeby przeprowadzenia badań przyjęto katalog obejmujący trzy kategorie barier, a mianowicie: bariery indywidualne, bariery organizacyjne oraz bariery technologiczne (Flaszewska, Zakrzewska-Bielawska, 2017, s. 346-347) i to one zostały poddane ocenom respondentów w badaniach pilotażowych.

\section{Metoda i próba badawcza}

D ążąc do realizacji celu, w artykule wykorzystano wyniki badań pilotażowych. Jak stwierdza A. Zakrzewska-Bielawska (2018, s. 108), zasadniczo postę- powanie takie zawiera się pomiędzy pilotażem ograniczonym i pilotażem kompleksowym. Wyniki, które zaprezentowano $\mathrm{w}$ niniejszym opracowaniu, uzyskano w ramach badań pilotażowych o charakterze kompleksowym. Badania przeprowadzono w III kwartale 2017 roku we współpracy z zewnętrzną firmą badawczą ASM - Centrum Badań i Analiz Rynku Sp. z o.o. Z uwagi na charakter badań ograniczono je do 55 wywiadów bezpośrednich i zastosowano technikę PAPI. Narzędziem badawczym był autorski kwestionariusz obejmujący trzy części, w tym:

- I z pytaniami merytorycznymi z zakresu badanej problematyki;

- II dotyczącą podstawowych informacji na temat przedsiębiorstwa;

- III dotyczącą informacji o respondencie.

Zgodnie $\mathrm{z}$ założeniami projektu, respondentami byli przedstawiciele przedsiębiorstw $\mathrm{z}$ województwa łódzkiego. W badaniu wzięło udział 26 kobiet i 29 mężczyzn. W większości były to osoby przed 50 rokiem życia (35 osób), z wykształceniem wyższym (33 osoby) i zajmujące różne stanowiska kierownicze (51 osób).

Odpowiedzi na pytania obejmujące przedmiot niniejszego artykułu uzyskano od przedstawicieli 55 przedsiębiorstw - w tym 3 dużych, 5 średnich i 12 małych i 35 mikro. Ze względu na podjętą problematykę wykluczono jednoosobowe działalności gospodarcze. Badane przedsiębiorstwa reprezentowały różne branże, przy czym większość $\mathrm{z}$ nich jako dominujący pod względem przychodów sektor, w którym działa, wskazała usługi (41 z 55 badanych firm). Obszar, na który działają, to rynek lokalny (18 podmiotów), regionalny (18 przedsiębiorstw), krajowy (15 firm), międzynarodowy (4 jednostki). Dominujące były także przedsiębiorstwa funkcjonujące na rynku powyżej 10 lat (28 firm) i takie, które $\mathrm{w}$ ostatnim roku odnotowały zysk (50 podmiotów).

\section{Dzielenie się wiedzą - perspektywa praktyczna}

Mierwszej kolejności respondentom przedstawiono katalog dziewięciu stwierdzeń dotyczących dzielenia się wiedzą i poproszono o wskazanie maksymalnie trzech odpowiedzi najlepiej oddających istotę poruszanego problemu. Badani mieli również możliwość uzupełnienia kafeterii o własne spostrzeżenia. Wskazania ankietowanych przedstawiono na rysunku 1.

$\mathrm{Na}$ podstawie uzyskanych wyników można stwierdzić, że w badanej grupie dzielenie się wiedzą rozumiane jest jako zachodzący samoistnie w każdej współczesnej organizacji ważny proces, generujący rozwiązania i korzyści, które zapewniają przedsiębiorstwu przewagę konkurencyjną. Zaskakuje fakt, że tylko pięciu badanych przyznało, że działania z zakresu dzielenia się wiedzą są dodatkowo premiowane w przedsiębiorstwach, które reprezentują. Co ciekawe, wszystkie odpowiedzi w przypadku tego stwierdzenia pochodziły od respondentów z mikroprzedsiębiorstw. 


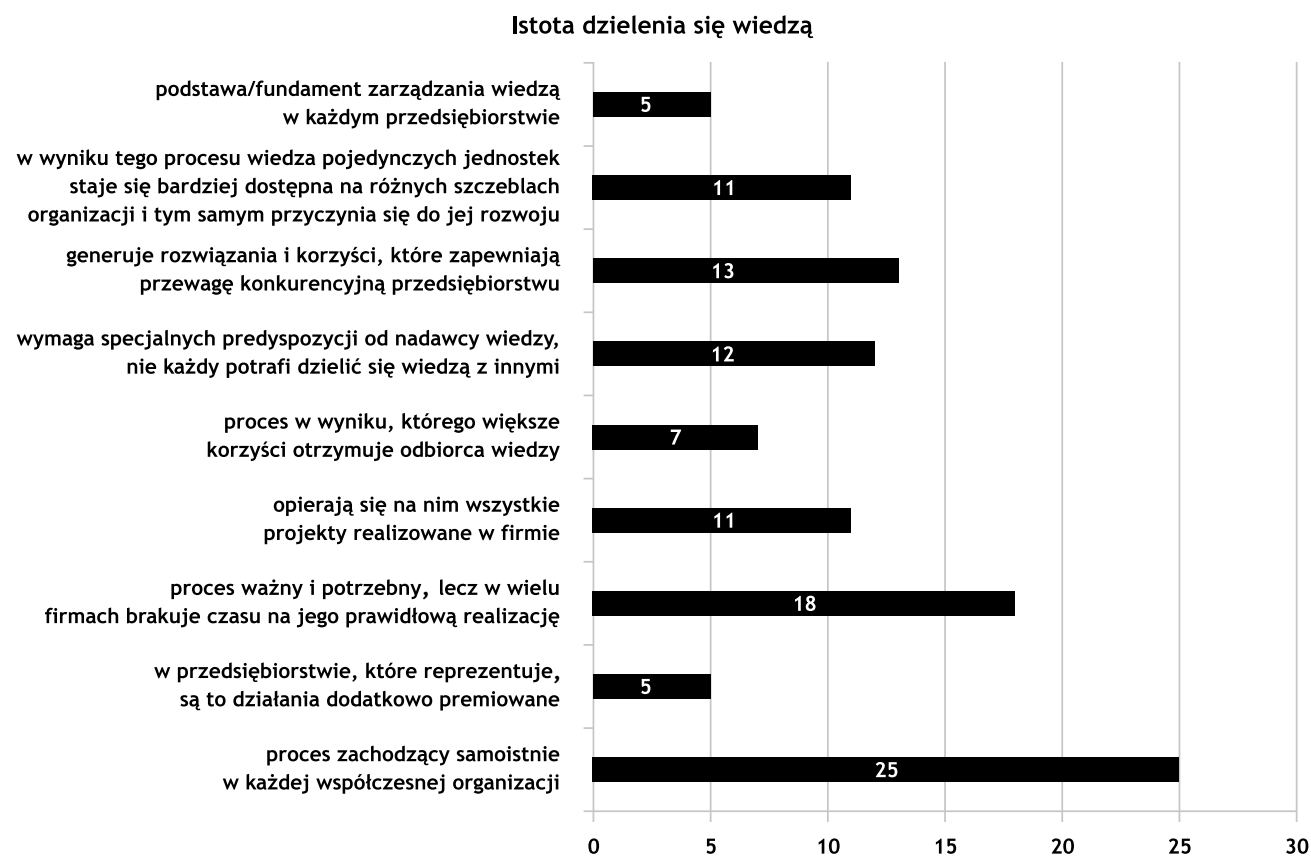

Rys. 1. Istota dzielenia się wiedzą według badanych Źródto: opracowanie własne

Tabela 1. Ocena aktualnego poziomu zaangażowania w działania z zakresu dzielenia się wiedzą przez badanych w zależności od wielkości firmy

\begin{tabular}{|c|c|c|c|c|c|}
\hline \multirow{2}{*}{$\begin{array}{c}\text { Wielkość } \\
\text { przedsiębiorstwa } \\
\text { mierzona } \\
\text { poziomem } \\
\text { zatrudnienia }\end{array}$} & \multicolumn{5}{|c|}{$\begin{array}{l}\text { Ocena aktualnego poziomu zaangażowania przedsiębior- } \\
\text { stwa w działania z zakresu dzielenia się w wiedzą }\end{array}$} \\
\hline & $\begin{array}{l}\text { bardzo } \\
\text { stabe }\end{array}$ & stabe & $\begin{array}{l}\text { umiarko- } \\
\text { wane }\end{array}$ & dobre & $\begin{array}{c}\text { bardzo } \\
\text { dobre }\end{array}$ \\
\hline mikro & & & 9 & 15 & 11 \\
\hline małe & & & 3 & 5 & 4 \\
\hline średnie & & & & 3 & 2 \\
\hline duże & & 1 & & & 2 \\
\hline razem & - & 1 & 12 & 23 & 19 \\
\hline
\end{tabular}

Źródło: opracowanie własne

Następnie zadaniem respondentów była ocena aktualnego poziomu zaangażowania przedsiębiorstwa w działania $\mathrm{z}$ zakresu dzielenia się wiedzą w skali od 1 do 5 , gdzie 1 oznacza bardzo słabe, 5 bardzo dobre. Odpowiedzi w zależności od wielkości firm przedstawiono w tabeli 1. Brak oceny najniższej i tylko jedna na poziomie 2 mogą świadczyć o wysokiej świadomości zarządzających badanymi przedsiębiorstwami w zakresie dzielenia się wiedzą. Mediana na poziomie 4 oznacza, że 50\% respondentów ocenia realizację tego procesu dobrze i bardzo dobrze. Co ciekawe, aż 26 wysokich ocen (łącznie 4 i 5) przyznali ankietowani $\mathrm{z}$ najmniejszych pod względem zatrudnienia podmiotów.

O świadomości zarządzających w zakresie dzielenia się wiedzą świadczą także odpowiedzi badanych na kolejne pytanie, w którym poproszeni zostali o wskazanie jednego z trzech stwierdzeń najlepiej opisujących działania firmy w tym obszarze. W 25 przypadkach pracownicy są informowani o różnych możliwościach udostępniania swojej wiedzy innym pracownikom i znają zalety tego typu działań, a 23 przedsiębiorstwa inwestują w szkolenia oraz organizują spotkania mające na celu uświadamianie pracownikom istoty i znaczenia dzielenia się wiedzą.

W dalszej części badań skoncentrowano się na barierach dzielenia się wiedzą. Pierwsze pytanie dotyczyło oceny ważności trzech wskazanych kategorii barier według skali od 1 do 5, gdzie 1 oznacza nieważną grupę barier, 5 bardzo ważną. Bariery indywidulane oraz organizacyjne oceniono stosunkowo wysoko, świadczy o tym wartość mediany $M=4$, nieco niżej ocenione zostały bariery technologiczne $(\mathrm{M}=3)$.

$\mathrm{W}$ ramach każdej z kategorii barier utrudniających dzielenie się wiedzą można wymienić wiele konkretnych przykładów. Zadaniem ankietowanych w kolejnym pyta- 
Tabela 2. Bariery występujące w badanych przedsiębiorstwach

\begin{tabular}{|c|c|}
\hline Bariery indywidualne & $\mathbf{N}$ \\
\hline Brak czasu & 34 \\
\hline Obawa/strach, że dzielenie się wiedzą może zagrozić bezpieczeństwu pracy & 12 \\
\hline Brak lub ograniczone zaufanie do ludzi, którzy mogą niewłaściwie wykorzystać wiedzę & 6 \\
\hline Różnice wieku & 4 \\
\hline Różnice płci & 2 \\
\hline Różnice w poziomach doświadczenia, edukacji & 12 \\
\hline Różnice językowe & 1 \\
\hline Różnice kulturowe & 2 \\
\hline Ochrona własności intelektualnej w obawie przed brakiem należnego uznania i docenienia ze strony menedżerów, kolegów & 7 \\
\hline Bariery organizacyjne & $\mathrm{N}$ \\
\hline Brak przejrzystego systemu uznaniowego i nagradzania & 23 \\
\hline Istniejąca kultura organizacyjna & 5 \\
\hline Hierarchiczna struktura organizacyjna & 12 \\
\hline Brak lub niejasna integracja pomiędzy inicjatywami z zakresu dzielenia się wiedzą a realizacją celów i strategii organizacji & 8 \\
\hline Brak przywództwa i ukierunkowania menedżerów na jasne komunikowanie korzyści i wartości praktyk dzielenia się wiedzą & 8 \\
\hline Fizyczne środowisko pracy i układ stanowisk ograniczający skuteczne praktyki dzielenia się wiedzą & 7 \\
\hline Wielkość jednostek biznesowych ograniczająca kontakty i proces dzielenia się wiedzą & 3 \\
\hline Bariery technologiczne & $\mathbf{N}$ \\
\hline Brak technicznego wsparcia & 17 \\
\hline Brak szkoleń dotyczących zapoznania pracowników z instrumentami wspierającymi dzielenie się wiedzą & 9 \\
\hline Nierealistyczne oczekiwania zatrudnionych wobec technologii & 8 \\
\hline Brak integracji systemów informatycznych z realizowanymi procesami, co spowalnia sposób wykonywania zadań & 7 \\
\hline Brak integracji systemów informatycznych z realizowanymi procesami, co spowalnia sposób wykonywania zadań & 7 \\
\hline $\begin{array}{l}\text { Niedopasowanie pomiędzy indywidualnymi wymaganiami i zintegrowanymi systemami informatycznymi, co ogranicza praktyki } \\
\text { dzielenia się wiedzą }\end{array}$ & 4 \\
\hline Niechęć do wykorzystania systemów informatycznych ze względu na brak znajomości i doświadczenia w pracy z nimi & 13 \\
\hline
\end{tabular}

Źródto: opracowanie wtasne

niu było wskazanie napotkanych trudności spośród skatalogowanych. Mieli oni jednocześnie możliwość uzupełnienia katalogu o własne propozycje. Szczegółowe wyniki przedstawiono w tabeli 2.

Powstaje więc pytanie, czy można, a jeśli tak, to w jaki sposób ograniczyć występowanie poszczególnych barier. Mając to na uwadze, w kolejnym pytaniu poproszono respondentów o wypowiedź na temat zachęt/warunków/ czynników sprzyjających dzieleniu się wiedzą. Za najbardziej sprzyjające dzieleniu się wiedzą większość ankietowanych uznała zachęty finansowe w postaci wyższego wynagrodzenia i dodatkowych premii (34 wskazania). Pojedyncze głosy dotyczył:

- uświadamiania pracowników/szkoleń finansowanych przez firmę;

- zapewnienia odpowiedniej atmosfery w pracy zachęcającej do utożsamiania się pracowników z firmą;
- klarownych procedur;

- ograniczenia obowiązków/krótszego czasu pracy/udogodnień w warunkach pracy;

- możliwości awansu;

- uznania przełożonych/środowiska;

- osobistej satysfakcji.

Zaskakuje fakt, że aż siedmiu respondentów nie potrafiło określić co stanowiłoby dla nich zachętę do dzielenia się wiedzą.

Z kolei na pytanie „czy dzielenie się wiedzą niesie za sobą wyłącznie pozytywne efekty”, respondenci zgodnie uznali, że tak, co więcej potrafili wskazać nawet po kilka przykładów w zależności od poziomu, którego dotyczą. Szczegółowe odpowiedzi zestawiono w tabeli 3.

Cieszy fakt, że respondenci dostrzegają i potrafią nazwać wiele efektów procesu dzielenia się wiedzą. $\mathrm{Na}$ poziomie jednostki najczęściej powtarzały się dwie 
Tabela 3. Efekty dzielenia się wiedzą w zależności od poziomu, którego dotyczą w opinii respondentów

\begin{tabular}{|c|c|}
\hline $\begin{array}{c}\text { Poziomy } \\
\text { dzielenia się } \\
\text { wiedzą }\end{array}$ & Efekty \\
\hline indywidualny & $\begin{array}{l}\text { - lepsza samoocena } \\
\text { - poprawa efektywności } \\
\text { - poprawa komunikacji } \\
\text { - rozwój osobisty } \\
\text { - większy poziom utożsamiania się z firmą } \\
\text { - wzrost kompetencji } \\
\text { - mniejszy stres } \\
\text { - większy autorytet } \\
\text { - lepsze zarządzanie czasem }\end{array}$ \\
\hline $\begin{array}{l}\text { zespołowy/ } \\
\text { grupowy }\end{array}$ & $\begin{array}{l}\text { - integracja zespołu, lepsza współpraca zespołowa } \\
\text { - lepsza komunikacja wewnętrzna } \\
\text { - lepsza organizacja pracy } \\
\text { - podniesienie/wyrównanie poziomu kompetencji między } \\
\text { - pracownikami } \\
\text { - utożsamianie się z firmą } \\
\text { - większe zaangażowanie pracowników/większa efektywność } \\
\text { - zracy } \\
\text { - lepsiększenie zaufania do współpracowników }\end{array}$ \\
\hline organizacyjny & $\begin{array}{l}\text { - podniesienie umiejętności rozwiązywania problemów } \\
\text { - poprawa efektywności funkcjonowania firmy/lepsza organizacja } \\
\text { pracy } \\
\text { - rozwój firmy/wzrost obrotów } \\
\text { - rozwój zespołu } \\
\text { transfer wiedzy i doświadczeń w obrębie organizacji }\end{array}$ \\
\hline
\end{tabular}

Źródło: opracowanie wtasne

odpowiedzi: wzrost kompetencji (25 wskazań) oraz rozwój osobisty (24 wskazania). Na poziomie zespołowym/grupowym zwracano przede wszystkim uwagę na większe zaangażowanie pracowników (19), a także poprawę współpracy (17 wskazań). W przypadku poziomu organizacyjnego podkreślano poprawę efektywności funkcjonowania firmy (25 wskazań) oraz jej rozwój (22 wskazań).

\section{Podsumowanie}

$\mathbf{P}$ rzeprowadzone badania pozwoliły na uzyskanie informacji dotyczących subiektywnej oceny procesu dzielenia się wiedzą w wybranych przedsiębiorstwach. Mając świadomość ograniczeń wynikających z pilotażowego charakteru badań (niewielkiej i niereprezentatywnej próby, jak również niedoskonałego jeszcze narzędzia badawczego), ustalono, że zdecydowana większość respondentów wysoko ocenia aktualne zaangażowanie przedsiębiorstwa $\mathrm{w}$ działania $\mathrm{z}$ zakresu dzielenia się wiedzą. Potwierdzeniem wysokich not są podejmowane przez większość badanych firm inicjatywy. Niestety, pomimo pozytywnej ogólnej oceny badanego procesu zauważono, że jego realizacja utrudniana jest przez wiele barier, a za najczęściej występujące uznano brak czasu, brak przejrzystego systemu uznaniowego i nagradzania oraz brak technicznego wsparcia. Z kolei za czynniki najbardziej sprzyjające dzieleniu się wiedzą większość respondentów uznała zachęty finansowe w postaci wyższego wynagrodzenia i dodatkowych premii.

Uzyskane wyniki badań mają pewne punkty wspólne $\mathrm{z}$ wynikami opisanymi przez innych autorów, np. w kwestii motywowania pracowników do aktywnego uczestnictwa w procesie dzielenia się wiedzą. M. Brzeziński i D. Mietlicka (2011, s. 62) stwierdzają, że powinno być ono wsparte odpowiednim systemem nagradzania. Jednak z przeprowadzonych przez nich badań ankietowych wśród pracowników przedsiębiorstwa produkcyjnego działającego na terenie województwa lubelskiego wynika, że oczekiwania pracowników są dalekie od stanu faktycznego. Podobne spostrzeżenia przedstawia także A. Ryszko (2015, s. 154), dokonując analizy danych zebranych z 292 przedsiębiorstw działających w Polsce. Autor dostrzega, że spośród ośmiu organizacyjnych praktyk dotyczących dzielenia się wiedzą to właśnie stosowanie zachęt dla pracowników do dzielenia się wiedzą wskazywano w zdecydowanie najmniejszym zakresie.

Tym, co wyróżnia niniejsze opracowanie, jest stworzony na podstawie wypowiedzi respondentów katalog pozytywnych efektów dzielenia się wiedzą z uwzględnieniem trzech poziomów, na których przebiega ten kluczowy proces.

Pamiętając o tym, że wszystkie sformułowane na podstawie przeprowadzonych badań wnioski dotyczą wyłącznie badanej grupy przedsiębiorstw, należy 
stwierdzić, że ciekawym wyzwaniem badawczym byłaby bardziej kompleksowa ocena procesu dzielenia się wiedzą na reprezentatywnej próbie przedsiębiorstw z różnych branż i sektorów oraz stworzenie bardziej obiektywnych narzędzi pomiaru.

Po przeanalizowaniu uzyskanych wyników, których tylko niewielki wycinek przedstawiono $\mathrm{w}$ niniejszym opracowaniu, autorka skorygowała narzędzie badawcze wykorzystane $\mathrm{w}$ badaniu pilotażowym ( $\mathrm{z}$ jednej strony ograniczając zbyt dużą swobodę respondentów $\mathrm{w}$ pytaniach otwartych, $\mathrm{z}$ drugiej zaś pomagając tym, którzy mają problem $\mathrm{z}$ nazywaniem pewnych kwestii) i zdecydowała o przeprowadzeniu dodatkowych badań $\mathrm{w}$ formie zogniskowanego wywiadu grupowego przed ostatecznym przystąpieniem do badań właściwych.

\section{dr inż. Sylwia Flaszewska \\ Politechnika Łódzka \\ Wydział Zarządzania i Inżynierii Produkcji \\ ORCID: 0000-0003-2022-5939 \\ e-mail: sylwia.flaszewska@p.lodz.pl}

\section{Bibliografia}

[1] Al Saifi S., Dillon S., McQueen R. (2016), The Relationship between Management Support and Knowledge Sharing: An Exploratory Study of Manufacturing Firms, „Knowledge and Process Management", Vol. 23, No. 2, pp. 124-135.

[2] Ardichvill A., Page V., Wentling T. (2003), Motivation and Barriers to Participation in Virtual Knowledge-sharing Communities of Practice, „Journal of Knowledge Management", Vol. 7, No. 1, pp. 64-77.

[3] Brzeziński M., Mietlicka D. (2011), Badanie i ocena procesu dzielenia się wiedza jako determinanty zmian w MŚP Polski Wschodniej - studium przypadku, Zeszyty Naukowe WSEI, seria Ekonomia, Nr 3/1, s. 53-71.

[4] Carvalho de Almeida F., Lesca H., Canton A.W.P. (2016), Intrinsic Motivation for Knowledge Sharing - Competitive Intelligence Process in a Telecom Company, „Journal of Knowledge Management”, Vol. 20, No. 6, pp. 1282-1301.

[5] Hislop D. (2013). Knowledge Management in Organizations, Oxford University Press, Oxford.

[6] Flaszewska S., Zakrzewska-Bielawska A. (2017), Struktura organizacyjna jako wsparcie dla procesu dzielenia się wiedza $w$ przedsiębiorstwie, „Organizacja i Kierowanie”, Nr 2(176), s. 343-354.

[7] Fullwood R., Rowley J. (2017), An Investigation of Factors Affecting Knowledge Sharing amongst UK Academics, „Journal of Knowledge Management”, Vol. 21, No. 5, pp. 1254-1271.

[8] Krok E. (2009), An Analysis of Employees' Inclination to Knowledge Sharing, „Polish Journal of Environmental Studies", Vol. 18, No. 3B, pp. 187-192.

[9] Krok E. (2009a), Personal Engagement in Knowledge Sharing, „International Journal of Management Cases”, Vol. 11, No. 1, pp. 11-22.

[10] Krok E. (2011), Analiza skłonności pracowników do dzielenia się wiedza na przykładzie badań wśród pracowników uczelni, Zeszyty Naukowe Uniwersytetu Szczecińskiego. Studia Informatica, Nr 27(643), s. 129-140.

[11] Kukko M. (2013), Knowledge Sharing Barriers in Organic Growth: A Case Study from a Software Company, „Journal of High Technology Management Research”, Vol. 24, No. 1, pp. 18-29.

[12] Riege A. (2005), Three-dozen Knowledge-sharing Barriers Managers Must Consider, „Journal of Knowledge Management", Vol. 9, No. 3, pp. 18-35.

[13] Ryszko A. (2015), Dzielenie się wiedzq w przedsiębiorstwach - wybrane problem i uwarunkowania, „Modern Management Review", Vol. XX, Nr 22(2), s. 149-159.

[14] Skrzypek E. (2018), Bariery dzielenia się wiedza w organizacji $w$ warunkach społeczeństwa informacyjnego, ,Nierówności Społeczne a Wzrost Gospodarczy”, Nr 53(1), s. $34-48$

[15] Ujwary-Gil A. (2012), Identyfikowanie i klasyfikowanie barier zarządzania wiedza, „Studia i Prace Kolegium Zarządzania i Finansów", Nr 115, s. 169-179.

[16] Zakrzewska-Bielawska A. (2018), Strategie rozwoju przedsiębiorstw. Nowe spojrzenie, PWE, Warszawa.

[17] Ziemba E., Eisenbardt M. (2016), Analiza wykorzystania kanałów komunikacji online $w$ dzieleniu się wiedza prosumentów, „Przegląd Organizacji”, Nr 11, s. 42-50.

\section{The Evaluation of Knowledge-sharing Process from the Practical Perspective}

\section{Summary}

The article discusses the issue of knowledge sharing in companies and aims to evaluate the process. In the pursuit of that objective the study uses the results of pilot studies carried out in 55 companies of various sizes from the Lodzkie Voivodship in the form of direct interviews using the PAPI technique. Based on the obtained results, it has been established that the vast majority of respondents highly appreciate the current company involvement in knowledge-sharing activities. Initiatives undertaken by the majority of the companies surveyed (employees are informed about the different ways of sharing knowledge with their colleagues and understand its advantages, business managers invest in trainings and organize meetings to make the employees aware of knowledge-sharing idea and its importance) are the confirmation of high notes. Unfortunately, the implementation of the analysed process is hindered by many barriers, and lack of time, lack of transparent discretionary and remuneration systems as well as lack of technical support have been considered the most common. On the other hand, as the most favourable factors enhancing knowledge-sharing process, the majority of respondents recognised financial incentives in the form of higher remuneration and additional bonuses.

\section{Keywords}

knowledge sharing, barriers to sharing knowledge, effects of knowledge sharing 